Jurnal Intelektualita: Keislaman, Sosial, dan Sains

Vol. 10 No. 1 (2021)

DOI: https://doi.org/10.19109/intelektualita.v10i1.8784

Copyright (C) 2021 Hari Febriansyah, Ainur Ropik, Afif Musthofa Kawwami

\title{
Optimalisasi Modal dalam Kontestasi Pemilihan Kepala Desa: Studi
} Kasus

\author{
Hari Febriansyah $^{1 *}$, Ainur Ropik ${ }^{1}$, Afif Musthofa Kawwami ${ }^{1}$ \\ ${ }^{1}$ UIN Raden Fatah Palembang, Indonesia
}

\begin{abstract}
Abstrak: Penelitian ini bertujuan untuk mengetahui bagaimana proses optimalisasi modal dalam kemenangan Nursalim sebagai kandidat calon kepala desa di desa Panca Mukti kecamatan Muara Telang Kabupaten Banyuasin pada tahun 2019. Penelitian ini menggunakan pendekatan kualitatif dengan metode studi kasus. Data dikumpulkan melalui wawancara, catatan, video, dan dokumen. Teknik analisis data melalui penjodohan pola antara data empirik dan pola yang telah diprediksikan, pembuatan eksplanasi, dan yang terakhir adalah analisis deret waktu. Penelitian ini menemukan bahwa kemenangan Nursalim atas kandidat lainnya dalam kontestasi pemilihan kepala desa (pilkades) desa Panca Mukti tahun 2019 adalah dikarenakan adanya faktor modal sosial yang dimiliki oleh Nursalim. Selain itu, dengan adanya modal sosial tersebut, Nursalim juga berhasil mengonversikan modal sosial tersebut menjadi modal ekonomi dan modal politik (dukungan para tokoh masyarakat) guna dapat memenangkan pemilihan kepala desa tahun 2019.
\end{abstract}

Kata Kunci: pilkada, modal sosial, modal politik, modal ekonomi, konversi

\begin{abstract}
This study aims to find out how the process of optimizing capital in Nursalim's victory as a candidate for village head in Panca Mukti village, Muara Telang district, Banyuasin district in 2019. This study uses a qualitative approach with a case study method. Data were collected through interviews, notes, videos, and documents. The data analysis technique is through pattern matching between empirical data and predicted patterns, making explanations, and finally time series analysis. This study found that Nursalim's victory over other candidates in the 2019 village head election contestation (pilkades) was due to Nursalim's social capital factor. In addition, with this social capital, Nursalim also succeeded in converting the social capital into economic capital and political capital (support from community leaders) in order to win the 2019 village head election.
\end{abstract}

Keywords: Pilkada, social capital, political capital, economic capital, conversion

\section{Pendahuluan}

Tahun 2019 merupakan tahun politik bagi masyarakat desa Panca Mukti Kecamatan Muara Telang Kabupaten Banyuasin, di mana desa tersebut telah mengadakan pemilihan kepala desa. Berdasarkan hasil rekapitulasi perolehan suara, salah satu kandidat bernama Nursalim berhasil terpilih menjadi kepala desa Panca Mukti tahun 2019.

Terdapat beberapa faktor yang mendukung kemenangan Nursalim, salah satunya adalah faktor modal sosial yang dimiliki oleh Nursalim. Tentunya hal ini tidak terlepas dari adanya interaksi sosial yang baik antara Nursalim dengan masyarakat desa Panca Mukti. Nursalim mampu

\footnotetext{
* Corresponding Author: Hari Febriansyah (harifeb23@gmail.com). UIN Raden Fatah Palembang, Indonesia
} 
membangun interaksi sosial tersebut dimulai dengan mencitrakan dirinya sebagai seorang figur yang baik kepada masyarakat desa. Figur seorang Nursalim yang dinilai agamis oleh masyarakat ikut andil dalam keberhasilannya membangun sebuah kepercayaan (trust) dengan masyarakat desa Panca Mukti. Maka dari itu, Nursalim dapat memenangkan pilkades desa Panca Mukti dengan mengalahkan kandidat lainnya.

Namun apabila mengacu pada penjelasan yang yang ungkapkan oleh Prof. Kacung Marijan (2006) bahwa seorang kandidat dalam pilkada harus memiliki 3 (tiga) modal utama yaitu modal politik (political capital), modal sosial, (social capital) dan modal ekonomi (economical capital), tentunya kemenangan Nursalim dalam kontestasi pilkades tersebut tidak terlepas juga dari faktor modal politik dan modal ekonomi. Beliau menambahkan bahwa di dalam proses pilkada sebagai arena kontestasi politik dengan memilih orang dan kompetisi antar kandidat, maka kandidat yang kemungkinan memenangkan pilkades manakala memiliki modal yang terbangun. Modal utama yang harus dimiliki para kandidat yang hendak mengikuti kontestasi didalam pilkades langsung, yaitu modal politik, modal sosial, dan modal ekonomi. Pasangan calon kepala desa itu memiliki peluang besar terpilih manakala memiliki akumulasi lebih dari satu modal, semakin besar pasangan calon yang mampu mengakumulasi tiga modal itu, semakin berpeluang terpilih sebagai kepala desa. Peluang terpilihnya pasangan kandidat merupakan bagian dari proses yang kompleks, maka tidak bisa dikatakan sebagai hasil hanya dari salah satu faktor saja atau modalitas tertentu (Adib, 2012; Putri, 2018; Vráblíková \& van Deth, 2017).

Berdasarkan hal tersebut, maka penelitian ini akan fokus kepada bagaimana Nursalim sebagai seorang kandidat pilkades memanfaatkan modal sosial yang dia miliki untuk mendapatkan dukungan modal politik dan ekonomi yang juga sangat berperan atas kemenangannya dalam kontestasi pilkades desa Panca Mukti pada tahun 2019.

\section{Metode Penelitian}

Penelitian ini menggunakan pendekatan kualitatif dengan metode studi kasus pada fenomena kemenangan seorang figur Nursalim dalam kontestasi pilkades desa Panca Mukti tahun 2019. Selanjutnya, dalam penelitian ini menggunakan snowball sampling dalam penentuan informan. Dalam mengumpul data menggunakan wawancara mendalam. Untuk teknik analisa data, menggunakan teknik analisa data studi kasus Robert K. Yin. terdapat beberapa tahapan dalam prosedur analasa data studi kasus ini, di antaranya; penjodohan pola antara data empirik dan pola yang telah diprediksikan, pembuatan eksplanasi, dan yang terakhir adalah analisis deret waktu. Selain itu, dalam proses analisis data, penelitian ini berlandaskan oleh beberapa teori dan konsep, diantaranya adalah teori modal sosial milik Pierre Bourdieu, konsep modal politik milik Kimberley Casey dan konsep 3 (modal); sosial, politik, ekonomi milik Prof. Kacung Marijan.

\section{Hasil dan Pembahasan:}

\section{Konversi Modal Sosial Menuju Modal Politik}

Casey (2006) yang dikutip oleh Sudirman Nasir (2009) mendefinisikan modal politik sebagai pendayagunaan keseluruhan jenis modal yang dimiliki seorang pelaku politik atau sebuah lembaga politik untuk menghasilkan tindakan politik yang menguntungkan dan memperkuat posisi pelaku politik atau lembaga politik bersangkutan. Casey lebih lanjut memerinci adanya empat pasar politik yang berpengaruh pada besaran modal politik yang dimiliki oleh seorang pelaku 
politik atau sebuah lembaga politik. Pasar politik pertama adalah pemilu karena pemilu adalah instumen dasar untuk pemilihan pemimpin dalam sistem demokrasi, pasar politik kedua adalah perumusan dan pelaksanaan kebijakan-kebijakan publik. Pasar politik ketiga adalah dinamika hubungan dan konflik antara pelaku politik dan lembaga politik dalam perumusan dan pelaksanaan kebijakan-kebijakan publik. Pasar politik keempat adalah pendapat atau pandangan umum (public opinion) mengenai pelaku politik atau lembaga politik itu. Berdasarkan apa yang telah dijelaskan oleh Casey, maka dapat disimpulkan bahwa modal politik juga dapat menjadi salah satu faktor kemenangan Nursalim dalam kontestasi pilkades desa Panca Mukti tahun 2019.

Hal yang perlu diperhatikan adalah bahwa modal politik kontestasi pilkada memiliki banyak bentuk, seperti dukungan partai politik, elit-elit politik dan lembaga masyarakat. Dalam penelitian ini modal politik yang dimaksudkan adalah dukungan para elit politik desa (tokoh masyararakat) yang mendukung Nursalim dalam keikutsertaannya di pilkades desa Panca Mukti tahun 2019.

Berdasarkan hasil analisis yang mendalam, modal politik yang dilmiliki oleh Nursalim sejatinya adalah sebuah bentuk konversi modal sosial yang merupakan faktor utama kemenangannya dalam kontestasi pilkades desa Panca Mukti tahun 2019.

Pada awal mulanya Nursalim sebelum menjadi kepala desa adalah seorang guru honorer di sebuah Sekolah Menengah Pertama Widya Darma Desa Sumber Mulya dan beliau bersuku Jawa. Berdasarkan keterangan beberapa tokoh masyarakat Desa Panca Mukti bapak Nursalim lebih aktif mengajar sebagai seorang guru. Selain mengajar Nursalim juga sebagai petani padi, warga lingkungan sekitar menganggap bapak Nursalim sebagai pribadi yang tegas dan berwibawa diketahui saat ada kegiatan kumpulan RT di rumah warga yang dilakukan beberapa bulan sekali.

Dari sinilah beberapa tokoh masyarakat menginginkan Nursalim mencalonkan diri menjadi kepala desa karena warga sekitar mengetahui bebet bobot dari bapak Nursalim. Berdasarkan hal tersebut, maka dapat dikatakan bahwa Nursalim telah berhasil mengkonversikan modal sosial yang beliau miliki menjadi modal politik yang sangat membantunya untuk ikut serta berkontestasi dalam pilkades Desa Panca Mukti tahun 2019. Dengan bermodalkan figuritas yang bagus, Nursalim berhasil meyakinkan para tokoh masyarakat desa untuk ikut mendukungnya dalam kontestasi pilkades, hingga pada akhirnya masyarakat desa juga terpengaruh untuk ikut mendukung Nursalim.

\section{Konversi Modal Sosial Menuju Modal Ekonomi}

Selain dari adanya nya modal sosial dan modal politik, modal ekonomi juga merupakan salah satu faktor kemenangan Nursalim dalam pilkades Desa Panca Mukti tahun 2019. Dalam setiap kontestasi pemilu tentunya setiap kandidat dalam mempersiapkan dan menghadapi kontestasi tersebut perlu modal ekonomi atau dana politik yang tidak sedikit, karena berkaitan dengan pembiayaan yang besar atau berdasarkan penggunaan dana politik itu sendiri.

Pengertian modal ekonomi berangkat dari pemahaman terhadap benda yang memiliki nilai ekonomis yang disimbolkan dengan uang/mata uang. Dalam perspektif ekonomi, modal bisa pula berupa investasi yang diberikan seseorang pada pihak lain, kemudian dipertukarkan dengan keuntungan berupa barang atau uang/jasa politik.

Modal ekonomi memiliki makna penting sebagai "penggerak" dan "pelumas" mesin politik 
yang dipakai. Di dalam musim kampanye misalnya sangat dibutuhkan biaya yang sangat besar untuk membiayai berbagai kebutuhan seperti mencetak poster, spanduk, membayar iklan, dan berbagai kebutuhan yang lainnya. Bahkan modal ekonomi dapat menjadi prasyarat utama untuk mencalonkan diri dalam kontestasi pemilu pada tingkat apapun.

Kembali kepada fokus penelitian ini, berdasarkan data yang didapat, dana finansial yang dimiliki kandidat lain selain Nursalim ternya sangat besar. Mengetahui kondisi finansial yang kalah besarnya dengan kandidat-kandidat lain, Nursalim berusaha mendapatkan dukungan finansial dari berbagai pihak. Terlepas dari motivasi apa yang melatar belakangi pihak-pihak tersebut dengan suka rela memberikan bantuan finansialnya kepada Nursalim. Dengan adanya faktor modal sosial dalam bentuk sebuah figuritas yang baik di mata Masyarakat desa, Nursalim berhasil mendapatkan dukungan modal ekonomi yang cukup untuk bisa beliau maksimalkan dalam prosses pemenangannya dalam kontestasi pilkades desa Panca Mukti tahun 2019.

Hal yang sangat menarik perhatian adalah kesukarelaan para relawan atau donatur untuk membantunya dalam hal modal finansial (ekonomi) adalah berasal dari ketertarikan para relawan atau donatur atas figuritas seorang Nursalim yang dinilai sangat bagus. Artinya Nursalim telah berhasil mengkonversikan modal sosial yang beliau miliki menjadi modal ekonomi yang sangat penting baginya untuk bisa memenangkan pilkades Desa Panca Mukti tahun 2019. Kemampuan beliau dalam mengkonversikan modal sosial menjadi modal ekonomi telah memunculkan sebuah kesukarelaan pada orang lain untuk bisa membantunya terutama dalam hal finansial atau pemodalan dalam pilkades. Hal tersebut tentunya memberikan keuntungan yang sangat besar pada Nursalim, terutama dengan kondisi finansial yang beliau miliki yang tidak sebanding dengan keuangan/finansial yang dimiliki oleh kandidatkandidat lainnya.

\section{Kesimpulan}

Modal sosial dalam kontestasi pemilu sejatinya merupakan hal yang perlu diperhatikan oleh setiap kandidat yang maju dalam pemilu. Faktanya pada kontestasi pilkades desa Panca Mukti tahun 2019 telah dimenangkan oleh Nursalim yang memiliki figur yang baik di mata masyarakat sebagai bentuk sebuah modal sosial yang dimiliki. Maka dapat disimpulkan bahwa faktor utama kemengannya adalah adanya modal sosial yang dimiliki oleh Nursalim. Figuritas yang baik di mata masyarakat desa menjadikan masyarakat tertarik untuk memilihnya sebagai kepala desa dalam kontestasi pilkades tersebut. Di samping itu, hal yang tidak bisa dikesampingkan juga adanya faktor modal politik dan modal ekonomi yang turut ikut serta mendukung kemenangan Nursalim dalam kontestasi pilkades tersebut. Nursalim behasil mengkonversikan modal sosial yang dimilikinya menjadi modal politik yang sangat berperan penting atas keikutsertaannya dalam kontestasi pilkada tersebut. Dengan figuritas yang dinilai baik, Nursalim berhasil mendapatkan dukungan dari beberapa tokoh masyarakat (elit politik desa) yang bersama-sama mendukung Nursalim. Selanjutnya, dengan kondisi di mana Nursalim adalah kandidat Kades yang memiliki modal finansial paling sedikit dibandingkan kandidat-kandidat lainnya, Nursalim berushaa mensiasati keadaan tersebut. Dia berhasil mendapatkan dukungan finansial dari beberapa relawan atau donatur. Kesukarelaan dari berbagai pihak tersebut tidak terlepas dari figuritasnya Nursalim (modal sosial) yang dinilai baik di mata para relawan/donatur. Konversi modal sosial menuju modal ekonomi tersebut sangat membantu 
Nursalim dalam proses pemenangannya dalam pilkades desa Panca Mukti tahun 2019.

\section{Daftar Pustaka}

Adib, M. (2012). Agen dan Struktur dalam Pandangan Piere Bourdieu. Jurnal BioKultur, 1(2), 91-110.

Casey, K. (2006). Defining Political Capital; Reconsideration of Bourdieuâs Interconvertibility Theory.

Kacung, M. (2006). Demokratisasi di Daerah, Pelajaran dari Pilkada Secara Langsung. Pustaka Eureka.

Putri, I. A. (2018). Jaringan Kekerabatan Matrilineal Sebagai Modal Sosial Perempuan Caleg dalam Pemilu 2014. Jurnal Antropologi: Isu-Isu Sosial Budaya, 19(2), 167-178.

Vráblíková, K., \& van Deth, J. W. (2017). Conducive contexts: The impact of collective and individual social capital on democratic citizenship. Acta Politica, 52(1), 23-42. 